\title{
Stigmaphyllon patricianum-firmenichianum (Malpighiaceae), a new species from Loyalty Islands, New Caledonia
}

\author{
Jean-François Butaud ${ }^{1,2}$ \\ I Conservation International, 58 bis avenue de la Victoire, 98800 Nouméa, New Caledonia 2 Consultant in \\ forestry and Polynesian botany, P.O. Box 52832 - 98716 Pirae, Tahiti, French Polynesia \\ Corresponding author: Jean-François Butaud (jfbutaud@hotmail.com) \\ Academic editor: Irina Belyaeva | Received 20 June 2015 | Accepted 3 August 2015 | Published 11 August 2015 \\ Citation: Butaud J-F (2015) Stigmaphyllon patricianum-firmenichianum (Malpighiaceae), a new species from Loyalty \\ Islands, New Caledonia. PhytoKeys 55: 119-127. doi: 10.3897/phytokeys.55.5472
}

\begin{abstract}
A new species of Stigmaphyllon (Malpighiaceae) is described: Stigmaphyllon patricianum-firmenichianum Butaud. It is restricted to the coral islands of Ouvéa, Lifou and Maré in the Loyalty Islands Province (New Caledonia) and is most similar to $S$. discolor (Gand.) C.E.Anderson, known from New Caledonia and Solomon Islands. Previously, plants now known as $S$. patricianum-firmenichianum were included in Stigmaphyllon taomense (Baker f.) C.E.Anderson, endemic to the northern part of Grande-Terre and Belep Islands (New Caledonia). A new circumscription of $S$. taomense is proposed. The regional key for New Caledonian species of Stigmaphyllon is updated.
\end{abstract}

\section{Keywords}

Stigmaphyllon, Ryssopterys, Malpighiaceae, Loyalty Islands, New Caledonia

\section{Introduction}

The family Malpighiaceae is represented by three native genera in New Caledonia: Acridocarpus Guill. \& Perr. with a single endemic species, Tristellateia Thouars with one indigenous species, and Stigmaphyllon A.Juss. with eight indigenous species, of which five are endemic (Morat et al. 2012); a sixth endemic is added here. 
Stigmaphyllon was recently revised by Anderson $(2011,1997)$ in both the Old and the New World. The Old World species, known from South-East Asia and the Western Pacific, traditionally had been assigned to the genus Ryssopterys A.Juss., which was found to be nested in Stigmaphyllon (Davis and Anderson 2010). Anderson (2011) recognized this group as Stigmaphyllon subg. Ryssopterys, comprising 21 species, of which ten were described as new.

Of the New Caledonian species of Stigmaphyllon, only one is known in the Loyalty Islands, which Anderson included in Stigmaphyllon taomense (Baker f.) C.E.Anderson, a species of Belep Islands and the northern part of Grande-Terre, the main island of the New Caledonian archipelago, ca. $200 \mathrm{~km}$ west of the Loyalty Islands (Anderson 2011; Baker 1921). Formerly, specimens from the Loyalty islands (Lifou or Maré) were labelled Ryssopterys timoriensis (DC.) A.Juss. (e.g., Schmid 1966, 1967), a synonym of S. timoriense (DC.) C.E.Anderson; S. timoriense is not known from New Caledonia (Anderson 2011).

Examination of living plants and herbarium specimens, and discussions with specialists of the genus Stigmaphyllon (C.E. Anderson, pers. comm. 2014) and New Caledonian flora (G. Gâteblé, pers. comm. 2014) revealed that the Loyalty Islands taxon differs from S. taomense. It is here described as S. patricianum-firmenichianum. Stigmaphyllon subg. Ryssopterys now includes 22 species, of which nine occur in New Caledonia.

\section{Systematics}

Stigmaphyllon patricianum-firmenichianum Butaud, sp. nov. urn:Isid:ipni.org:names:77149114-1

Type. New Caledonia, Loyalty Islands, Ouvéa, Banutr, bord de route menant à l'aéroport, $20^{\circ} 38.345^{\prime} \mathrm{S}, 166^{\circ} 33.726^{\prime} \mathrm{E}, 11 \mathrm{~m}$ alt., liane de $5 \mathrm{~m}$ à fleurs mâles de couleur jaune, en lisière de forêt secondaire à Podonephelium et Elattostachys, 17 December 2013, J.-F. Butaud 3346 (holotype NOU!, isotype P!).

Diagnosis. Stigmaphyllon patricianum-firmenichianum is most similar to S. discolor (Gand.) C.E.Anderson and S. mcphersonii C.E.Anderson in the tomentose vesture of the abaxial surface of the blade which differentiates them from the other New Caledonia Stigmaphyllon species. Stigmaphyllon patricianum-firmenichianum differs from $S$. discolor by the number of stamens, respectively 10 and 12-16, and by the number of flowers in each umbel, respectively 4-9 and 8-18(-20), and from S. mcphersonii by the number of functional styles of the male flowers, respectively 3 and none (styles absent or rarely 1 , rudimentary and without stigma), by the sepals length, respectively 2.8-3 $\mathrm{mm}$ and $1.5-2 \mathrm{~mm}$, by the petals length, respectively $8-10 \mathrm{~mm}$ and $6-27 \mathrm{~mm}$, and by the dorsal wing of samara, respectively $2.6-2.9 \mathrm{~cm}$ and $1.7-2 \mathrm{~cm}$ long.

Description. Liana to over $8 \mathrm{~m}$ long; young stems tomentose, the vesture caducous in older parts, eventually becoming glabrate to glabrous. Blade of the larger leaves $4.8-7.5 \times 3-5.4 \mathrm{~cm}$, suborbicular to broadly ovate or ovate, apex emargin- 


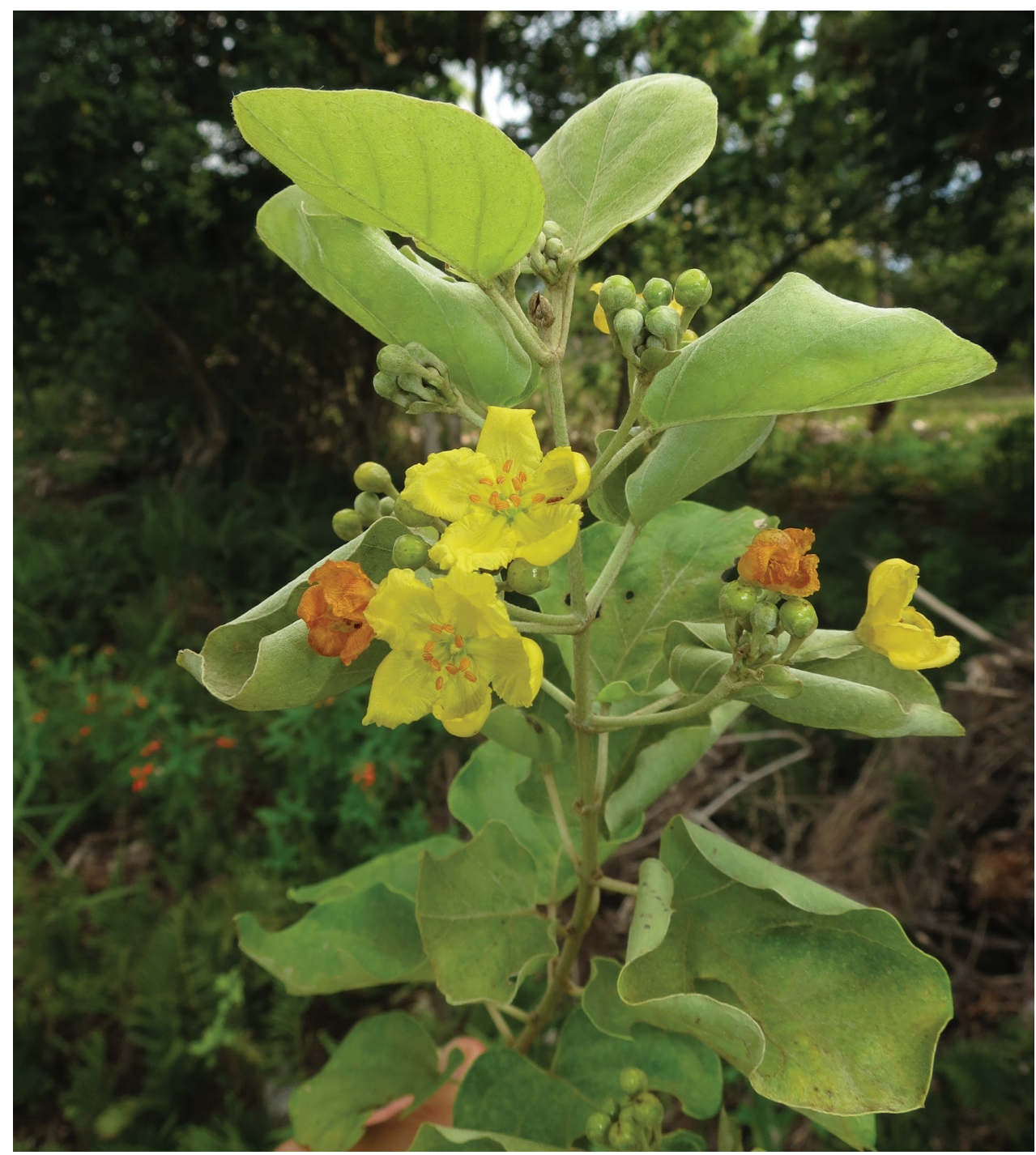

Figure I. Male flowers of Stigmaphyllon patricianum-firmenichianum Butaud on Ouvéa atoll in December 2013 (specimen Butaud 3346).

ate to obtuse, acute or apiculate, base cordate to truncate, adaxially tomentose or sericeous when young, soon glabrescent to glabrous or with some hairs retained on costa, secondary veins and near the petiole, abaxially tomentose, eventually sericeous in older leaves, but in some leaves the vesture unevenly deciduous except close to the costa and at the apex and the petiole where always dense, secondary veins 4-7 pairs, prominent abaxially; marginal glands $0.1-0.3 \mathrm{~mm}$ diam.; petiole $1.3-2.6 \mathrm{~cm}$ long, tomentose, in older leaves the vesture sloughed off in patches, with a pair of glands borne at apex or partly on the base of the blade above insertion of the petiole, 
each gland $0.5-0.6 \mathrm{~mm}$ diam., slightly prominent; stipules 1 on each side of petiole, narrowly triangular, bractlike, to $1 \mathrm{~mm}$ long, abaxially tomentose, sometimes hidden by stem vesture. Hermaphrodite flowers 5-9 in each umbel or condensed pseudoraceme; umbels solitary or borne in dichasia; inflorescence stalks $1.1-2.9 \mathrm{~cm}$ long, often terminating a pair of foliaceous bracts, peduncles $3-5 \mathrm{~mm}$ long, pedicels 4-8 $\mathrm{mm}$ long, both tomentose; bracts c. $1 \mathrm{~mm}$ long, narrowly triangular, bracteoles c. $1 \mathrm{~mm}$ long, narrowly triangular, bracts and bracteoles abaxially tomentose. Sepals $5,2.8-3 \times 2.2-2.5 \mathrm{~mm}$, orbicular or broadly ovate, abaxially densely sericeous but often glabrous along the margin. Petals 5 , yellow, obovate with a claw $0.5-1 \mathrm{~mm}$ long, limb 8-10 × 5.5-7 mm, base acute or truncate, margin subentire or shallowly erose. Stamens 10; filaments c. $3 \mathrm{~mm}$ long; anthers without apiculum, glabrous. Ovary c. $1.6 \mathrm{~mm}$ long; 3 free styles c. $3.5 \mathrm{~mm}$ long, c. $0.1 \mathrm{~mm}$ diam., stigma c. 0.3 $\mathrm{mm}$ diam., peltate. Male flowers in inflorescences, and with sepals and petals, similar to hermaphrodite flowers: stamens 10, filaments c. $3 \mathrm{~mm}$ long; anthers without apiculum, glabrous; ovary rudimentary, a tiny mound of tissue embedded in a tuft of hairs; styles 3, c. $3 \mathrm{~mm}$ long, c. $0.1 \mathrm{~mm}$ diam., free or 2 variously united, stigma c. $0.3 \mathrm{~mm}$ diam., peltate. Fruit: a schizocarp splitting into 3 samaras, pedicels 4-7 $\mathrm{cm}$ long. Dorsal wing of samara $2.6-2.9 \times 1.1-1.4 \mathrm{~cm}$; nut $4-5 \mathrm{~mm}$ long, c. $4 \mathrm{~mm}$ diam., broadly ovoid to spheroid, with prominent ridges, lateral winglets absent; areole $2.5-3 \mathrm{~mm}$ long and wide.

Phenology. Flowers (emitting a pleasant odor) from November to April; fruits from February to May.

Distribution. New Caledonia, endemic to Loyalty Islands; known only from Ouvéa, Lifou and Maré islands. Not recorded on the smaller islands of BeautempsBeaupré, Tiga and Walpole.

Habitat. This species is restricted to the calcareous soils of uplifted atolls between 5 and $90 \mathrm{~m}$ elevation, in littoral open forest or shrubland, and in the interior on plateau open forest or shrubland. It is also commonly found among the naturally open and shrubby vegetation of the cliffs between littoral and plateau. This vine is characteristic of fallows, young shrublands and secondary forests following shifting cultivation. It is also commonly found along roads and close to villages in open and sunny areas. The vegetation is often composed of trees and shrubs, such as Acacia spirorbis Labill., Acronychia laevis J.R.Forst. \& G.Forst., Elattostachys apetala (Labill.) Radlk., Glochidion billardierei Baill., Morinda citrifolia L., Pipturus argenteus (G.Forst.) Wedd. var. lanosus Skottsb., Podonephelium homei (Seem.) Radlk., and Polyscias bracteata (RVig.) Lowry subsp. bracteata.

Conservation status. Using the categories and criteria of IUCN (2001), the IUCN Red List Category Least Concern (LC) for S. patricianum-firmenichianum is proposed. Indeed, this is a common vine of anthropized areas on the three islands, i.e. in villages, cultivated areas, fallows, shrubland, roadsides, and open littoral forest on the calcareous cliffs. No decline is estimated or has been documented.

Etymology. I am pleased to name this new species for Patrick Firmenich (b. 1962), former Chief Executive Officer of Firmenich, a leading Swiss company creating 


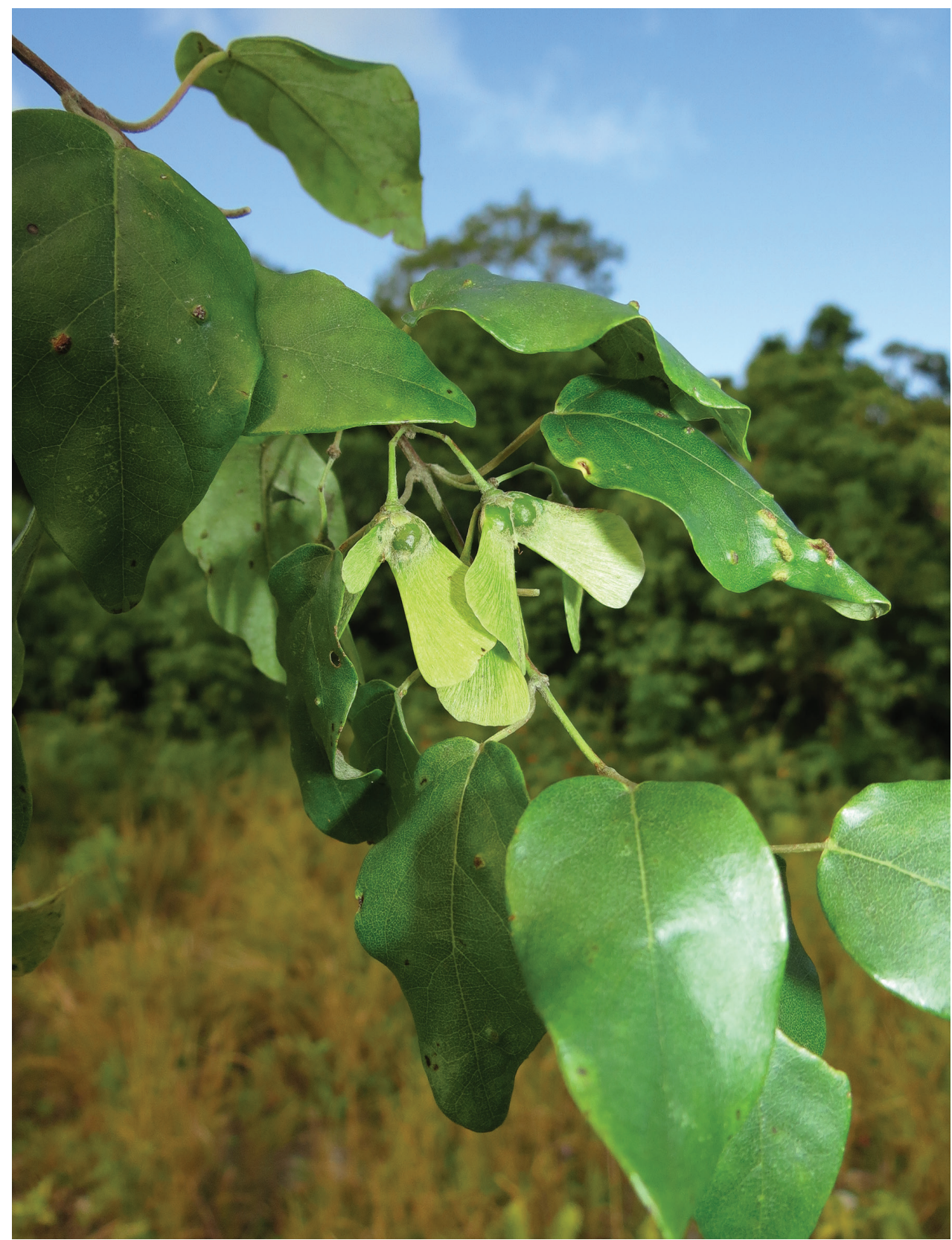

Figure 2. Fruits of Stigmaphyllon patricianum-firmenichianum Butaud on Lifou island in April 2015 (specimen Butaud 3426).

fragrances and flavors. The Firmenich Charitable Foundation is supporting the sustainable management of the Loyalty Islands biodiversity, especially on Ouvéa atoll, a natural World Heritage site. 
Common names. The common names recorded for $S$. patricianum-firmenichianum are "watoma" on Lifou (herbarium specimens Deplanche 74, Däniker 2468 \& Bergeret 86; Däniker 1932; Lenormand 1999, 1968) and "tai" on Maré (herbarium specimen Däniker 2497; Däniker 1932; Dubois 1971; Lormée et al. 2011). No common name has been recorded on Ouvéa.

Discussion. Stigmaphyllon patricianum-firmenichianum is the sole member of the genus Stigmaphyllon in the Loyalty Islands. It is allied with S. discolor and S. mcphersonii with which it shares an abaxial tomentose vesture of the blade. Its inclusion under S. taomense, a species with an abaxially sericeous blade, by Anderson (2011), may stem from the patchily deciduous vesture of some leaves, which can give the impression of a sericeous blade. Moreover, S. patricianum-firmenichianum, S. mcphersonii and S. taomense have all 10 stamens, whereas $S$. discolor bears 12-16 stamens. Nevertheless, its closest affinity in New Caledonia apparently is with $S$. discolor, which occurs on most of the southern part of Grande-Terre and Isle of Pines. In South-East Asia and the Western Pacific, it is most similar to $S$. albidum (Blume) C.E.Anderson, which can be differentiated by the absence of a style in male flowers. This new species is also clearly different from the widely distributed $S$. timoriense, which has male flowers usually without styles and blades abaxially sericeous to glabrate.

Specimens examined. Loyalty Islands. Lifou, E. Deplanche 74 (P scan!); Lifou, Mou, 28 November 1925, A.U. Däniker 2468 (Z [3] scan!); Lifou, 1927, C. Bergeret 86 (P scan!); Lifou, We-Kodegni, forêt mi-dense, halliers, 14 February 1966, M. Schmid 1038 (NOU!, P scan!, MICH n.v.); Lifou, Mutchaweng, 30 m, forêt sur terrain plat caillouteux, 18 February 1974, H. MacKee 28179 (P scan!, MICH n.v.); Lifou, hauteurs au SE du Cap Lafon, 90 m, forêt saxicole, 20 February 1974, H. MacKee 28295 (P scan!, MICH n.v.); Lifou, Wanaham, bord de route menant à Hnacaom, $20^{\circ} 47.037^{\prime} \mathrm{S}, 167^{\circ} 13.979^{\prime} \mathrm{E}, 38 \mathrm{~m}$ alt., liane de $5 \mathrm{~m}$ à fleurs femelles jaunes odorantes et jeunes fruits, en lisière de forêt secondaire à Acacia, Glochidion, Polyscias, Acronychia, Secamone, 15 April 2015, J.-F. Butaud 3424 (NOU!, P!); Lifou, Xodre, bord de route menant au plateau, $21^{\circ} 7.682^{\prime} \mathrm{S}, 167^{\circ} 24.403^{\prime} \mathrm{E}, 58 \mathrm{~m}$ alt., liane de $5 \mathrm{~m}$ à fruits matures, en lisière de forêt de corniche à Ficus virgata, Pipturus, Mucuna, Morinda, 15 April 2015, J.-F. Butaud 3426 (NOU!, P!); Maré, Tadine, 15 December 1925, A.U. Däniker 2497 (Z [2] scan!).

\section{Circumscription of Stigmaphyllon taomense}

Stigmaphyllon taomense (Baker f.) C.E.Anderson, Blumea 56 (2011) $99 \equiv$ Ryssopterys taomensis Baker f., J. Linn. Soc., Bot. 45 (1921) 278.

Type. New Caledonia, Mt Taom, 200 ft, 30 November 1914, R.H. Compton 2286 (holotype BM scan!).

Discussion. The description given by Anderson (2011) for $S$. taomense is still correct, despite the separation of $S$. patricianum-firmenichianum from it. The examination 
of $S$. taomense specimens in NOU has shown some differences between Belep Islands and Northern Grande-Terre plants, especially the absence of marginal glands on the blade for the latter. Study of more specimens of both provenances may lead to the description of a new species endemic to Belep Islands.

Specimens examined. New Caledonia, Grande Terre. Pain de Sucre, 22 December 1950, A. Guillaumin \& M.G. Baumann-Bodenheim 9734 (Z scan!, P scan!, BRI n.v.); Crêtes calcaires rocheuses au SE de la corne de Koumac, 250 m, 27 December 1972, H. MacKee 26101 (P scan!, MICH n.v.); Koumac, 13 February 1969, M. Schmid 2705 (NOU!, P scan!); Ile Art, plateau Nord, 150 m, 8 December 1975, H. MacKee 30401 (NOU!, P scan!, MICH n.v.); Belep, 9 December 1975, M. Debray 2466 (P scan!); Koumac, Oué Ambouch, 200 m, 24 January 1979, H. MacKee 36515 (NOU!, P scan!, MICH n.v); Belep, December 1978, D. Bourret 1873 (NOU!)

\section{Key to New Caledonian species of Stigmaphyllon}

(adapted from Anderson 2011)

1 Petiole flanked on each side by 2-3 stipules, to $2 \mathrm{~cm}$ long and leaflike....

S. grandifolium

- $\quad$ Petiole flanked on each side by 1 triangular stipule, to $1.5 \mathrm{~mm}$ long and bractlike (never leafy) ................................................................2

2 Blades abaxially tomentose, the vesture patchily deciduous in some leaves but still dense at the base or the apex................................................... 3

- Blades abaxially sericeous or glabrous on the entire surface .......................5

3 Umbels with 8-18(-20) flowers; stamens 12-16 ...................... S. discolor

- Umbels with 4-9 flowers; stamens 10 ................................................4

4 Sepals 2.8-3 mm long; petals 8-10 mm long; male flowers with 3 styles, all free or 2 united; dorsal wing of samara $2.6-2.9 \mathrm{~cm}$ long.

S. patricianum-firmenichianum

- $\quad$ Sepals 1.5-2 mm long; petals 6-7 mm long; male flowers without functional styles (styles absent or rarely 1, rudimentary and without stigma); dorsal wing of samara $1.7-2 \mathrm{~cm}$ long.....

S. mcphersonii

5 Blades abaxially sericeous, the vesture patchily deciduous in older leaves

S. taomense

- $\quad$ Blades abaxially glabrous or with some scattered hairs

6

6 Pedicels entirely glabrous or the basal $1 / 4$ sericeous, red ..... S. gymnopodum

- $\quad$ Pedicels densely sericeous, green but the colour obscured by the vesture..... 7

7 Stamens 10; petals 6-7 mm diam.; male flowers without styles; blades 0.3$2.7 \mathrm{~cm}$ wide, linear to oblong to narrowly elliptical or narrowly lanceolate...

S. angustifolium

- $\quad$ Stamens 12-18; petals 9-10 mm diam.; male flowers with styles; blades 2.5$6 \mathrm{~cm}$ wide, narrowly lanceolate to elliptical to broadly elliptical to ovate 


\section{Acknowledgments}

I am grateful to the Province des Iles Loyauté (PIL) which has initiated and supported recent investigations on the Loyalty Islands flora and to the Herbier du Centre IRD de Nouméa (NOU) for access to its Stigmaphyllon collections.

I thank also the taxonomists Christiane Anderson and Gildas Gâteblé for helpful discussions on Loyalty Islands Stigmaphyllon, and, together with David Lorence (National Tropical Botanical Garden, Hawai'i), for their important comments and corrections of previous drafts of this paper. I appreciate review comments by Werner Greuter and Hajo Esser.

I am also grateful to George Kakue, Luen Iopue, Meri Thupalua (PIL) and JeanChristophe Lefeuvre (Conservation International) for their support and interest in establishing a Flora of Loyalty Islands.

\section{References}

Anderson C (1997) Monograph of Stigmaphyllon (Malpighiaceae). Systematic Botany Monographs 51: 1-313. doi: 10.2307/25027873

Anderson C (2011) Revision of Ryssopterys and transfer to Stigmaphyllon (Malpighiaceae). Blumea 56: 73-104. doi: 10.3767/000651911X573444

Baker EG (1921) Plants from New Caledonia and the Isle of Pines. Polypetalae. Journal of the Linnean Society, Botany 45: 245-325.

Däniker AU (1932) Ergebnisse der Reise von Dr. A.U. Däniker nach Neu-Caledonien und den Loyalty-Inseln (1924-1926) 4. Katalog der Pteridophyta und Embryophyta siphonogama. Forstsetzung. II. Teil. Beiblatt zur Vierteljahrsschr. Naturf. Ges. Zürich 77(19): 115-235.

Davis CC, Anderson WR (2010) A complete phylogeny of Malpighiaceae inferred from nucleotide sequence data and morphologhy. American Journal of Botany 97: 2031-2048. doi: 10.3732 /ajb. 1000146

Dubois MJ (1971) Ethnobotanique de Maré, Iles Loyauté (Nouvelle Calédonie) (Fin). Journal d'agriculture tropicale et de botanique appliquée 18(9-10): 310-371. doi: $10.3406 /$ jatba. 1971.6867

IUCN (2001) IUCN Red List categories (version 3.1). IUCN Species Survival Commission, Gland, Switzerland. http://www.iucnredlist.org/info/categories_criteria2001

Lenormand MH (1968) Vocabulaire des noms de plantes médicinales et alimentaires utilisées par les Mélanésiens de Lifou (Iles Loyalty). Journal d'Agriculture Tropicale et de Botanique Appliquée 15(4-6): 173-194. doi: 10.3406/jatba.1968.2979

Lenormand MH (1999) Dictionnaire de la langue de Lifou, le Qene Drehu. Le-Rocher-àla-Voile, Nouméa.

Lormée N, Cabalion P, Hnawia ES (2011) Hommes et plantes de Maré, îles Loyauté, NouvelleCalédonie. IRD Editions. 
Morat P, Jaffré T, Tronchet F, Munzinger J, Pillon Y, Veillon J-M, Chapolin M (2012) The taxonomic database "FLORICAL " and characteristics of the indigenous flora of New Caledonia. Adansonia sér. 3 34(2): 177-219. doi: 10.5252/a2012n2a1

Schmid M (1966) Espèces observées à Lifou au cours de la mission et espèces signalées par Däniker dans le compte-rendu de son voyage aux îles Loyautés. ORSTOM, Nouméa. Schmid M (1967) Florule de Maré - cryptogames vasculaires et phanérogames. ORSTOM, Nouméa. 